\title{
Venture capital reputation: a blessing or a curse for entrepreneurial firm innovation-a contingent effect of industrial distance
}

Han Liang, Gang Liu* and Jianling Yin

*Correspondence: liugang@rmbs. ruc.edu.cn

School of Business, Renmin University of China, 59

Zhongguancun Street, Haidian District, Beijing 100872, China

\begin{abstract}
This study investigates whether venture capital reputation is a blessing or a curse for entrepreneurial firm innovation by using data from 1553 observations of venture capital investments on entrepreneurial firms in China's New Over-the-Counter (OTC) Market. Advantages that venture capital brings to entrepreneurial firms have been widely acknowledged in extant research. However, our research emphasizes the potential resource outflows rather than inflows when firms are embedded in a shared reputable venture capital, and finds that the curse effect of venture capital reputation on entrepreneurial firms is manifested. Furthermore, we develop the concept of venture capital "intra-industrial reputation" and "extra-industrial reputation" to give a contingent answer to the "blessing or curse" question. The conclusions are drawn indicating that the curse effect is contingent on industrial distance. Venture capital intra-industrial reputation is positively linked to entrepreneurial firm innovation, whereas extra-industrial reputation exerts a strong negative impact, which is responsible for the curse effect.
\end{abstract}

Keywords: Venture capital reputation, Intra-industrial reputation, Extra-industrial reputation, Curse effect, Entrepreneurial firm innovation, Industrial distance

\section{Introduction}

Despite the prevalence of venture capital (VC) in the entrepreneurship field, there are still mixed results about influences VC can impose on entrepreneurship innovation. An extensive body of research has suggested that $\mathrm{VC}$ reputation promotes entrepreneurial firm performance by providing a resource inflow through signaling effect and resource effect (Gu and Lu 2014; Hochberg et al. 2007; Krishnan et al. 2011; Lee et al. 2011; Megginson and Weiss 1991; Nahata 2008). The blessing effect can also be found in not only traditional IPO review but entrepreneurial firm innovation literature (Bernstein et al. 2016; Chemmanur et al. 2014; Dutta and Folta 2016; Zhang 2015; Wang et al. 2018). The exhaustive entrepreneurial research has shown that constrained by a "liability of newness," entrepreneurial firms have little choice but to obtain certification and

(c) The Author(s). 2019 Open Access This article is distributed under the terms of the Creative Commons Attribution 4.0 International License (http://creativecommons.org/licenses/by/4.0/), which permits unrestricted use, distribution, and reproduction in any medium, provided you give appropriate credit to the original author(s) and the source, provide a link to the Creative Commons license, and indicate if changes were made. 
much-needed resources for innovation through outsiders (Baum et al. 2000; Gulati and Higgins 2003; Pahnke et al. 2015; Zhang and Li 2010), among which reputable VC maintains the first place. The innovation promotion and long-term performance enhancement for entrepreneurial firms that receive $\mathrm{VC}$ grants are also empirically verified (Chemmanur et al. 2011; Croce et al. 2016; Gompers and Lerner 1999; Krishnan et al. 2011).

However, in reality, the situation is far more complicated. For instance, the sharp conflict between founder and venture capitalist caused NVC, a leading lighting supplier in China, to experience a great labor strike, resulting in the founder's resignation and a sharp drop in performance. In fact, such an occurrence is rather common in the business world, exhibiting the curse effect for entrepreneurial firm innovation. Even though one has received temporal benefits, there are still some potentially negative effects resulting from inconsistent interests or competitive leakage, as shown through limited research (Pahnke et al. 2015; Pollock 2004). Inconsistent with the blessing perspective, Arvanitis and Stucki (2014) find little evidence to support positive and time-persistent effects of early stage $\mathrm{VC}$ on entrepreneurial firm innovation. Lee et al. (2011) explore the contingent value of VC reputation, suggesting that reputable $\mathrm{VC}$ can provide substantive benefits on post-IPO performance only when it is involved in early-round investment.

More generally, extant research has largely focused on the blessing effect of $\mathrm{VC}$ reputation, documenting advantages that add to entrepreneurial firms. However, the curse effect of reputation, has received little attention. What are the downsides of VC reputation for entrepreneurial firm innovation? Are there resource outflows rather than resource inflows when firms are embedded in a shared VC network?

Building on the above-mentioned ideas, this study develops a theory of the $\mathrm{VC}$ reputation curse effect, and conceptualizes why and under which conditions $\mathrm{VC}$ reputation will negatively impact entrepreneurial firm innovation. This study uses China's New Over-the-Counter (OTC) Market and the VC industry as empirical context, and collects a unique dataset consisting of 1553 observations to test broad support for our findings. First, we develop our arguments in the context of the investment networkVCs and their backed entrepreneurial firms, on whether VC reputation is a blessing or a curse for backed firm innovation. Then, we explore the moderating factor characterizing the industrial nature of reputation. Based on that, we further test the effects from VC intra-industrial and extra-industrial reputation.

Our research makes two contributions. First, we enrich the resource curse view of VC reputation on entrepreneurial firm innovation within the dependent relationship where resource-constrained entrepreneurial firms rely on reputable $\mathrm{VC}$ and act as low-power actors. Our primary hypothesis empirically indicates a negative correlation between VC reputation and backed firm innovation performance, resulting from unwanted resource outflows exceeding resource inflows. Second, we argue that not all kinds of $\mathrm{VC}$ reputation can impose the same impact on firms by providing a more fine-grained conceptual analysis of $\mathrm{VC}$ reputation, and find that the curse effect of $\mathrm{VC}$ reputation on firm innovation comes from extra-industrial reputation, but not intra-industrial reputation. Our research gives an "if-then" not "either-or" answer to the question-blessing or curse, by emphasizing the industrial fit between VC reputation and backed entrepreneurial firms. 


\section{Literature review and hypothesis \\ VC reputation: A blessing or a curse}

Reputation is a representation of a firm's past actions and future prospect (Fombrun 1996), acting as a signal for the otherwise unobservable quality and potential of a firm (Rindova et al. 2005), characterized as uncertainty, especially in an innovation context. However, in the absence of track records and performance histories, it is generally difficult for entrepreneurial firms to establish a valid reputation in a short time, as this requires the "certification" of third-party intermediaries' reputation (e.g., reputable VC) (Nahata 2008; Tang and Li 2018).

Consistent with the idea that VC reputation is of necessity particularly in an innovation context, one stream argues that $\mathrm{VC}$ reputation takes a signaling role, suggesting that it can serve as a certification agent to infer the quality of backed firms and alleviate innovation uncertainty (Krishnan et al. 2011; Lee et al. 2011; Megginson and Weiss 1991; Nahata 2008). As Krishnan et al. (2011) note, reputable VC is better qualified to select well-qualified targets. As such, VC reputation grants the quality endorsement and legitimacy to its backed entrepreneurial firms (Stuart et al. 1999), and helps to acquire more resources from other parties to support the firms' innovation activities.

The other stream focuses on the resource role, which is also called the "substantive role" in Lee et al. (2011), emphasizing the resource-provision function of VC reputation. Directly, VC with a high reputation has a stronger financing capability and provides more value-added services accumulated through rich experiences (Nahata 2008; Tang and Li 2018). Such greater industry knowledge can generate a better resource fit between $\mathrm{VC}$ and backed firms. This mechanism to nurture backed firms' innovation is evidenced in the context of corporate venture capital (Chemmanur et al. 2014). Indirectly, given the sophisticated network nature, $\mathrm{VC}$ with a high reputation is embedded in a broader and better-quality network. As Hochberg et al. (2007) point out, measures of VC network centrality are correlated with VC reputation. Consequently, reputable VC provides access to valuable resources like financial resources, privileged information, and expert advice through networking, including potential investors and firms via a shared VC (Bellavitis et al. 2014; Hochberg et al. 2007; Lee et al. 2011; Sahlman 1990; Stuart et al. 1999). For example, Wang et al. (2018) and Bellavitis et al. (2014) find that VC's network has a significantly strong impact on a firm's success and innovation performance. Such a positive resource spillover effect is conducive to entrepreneurial firms in overcoming their resource constraints for promoting innovation.

Therefore, consistent with the mainstream, we recognize the blessing effect of VC reputation and propose the hypothesis that:

Hypothesis 1a: VC reputation will bring about the blessing effect. In other words, VC reputation is positively associated with entrepreneurial firm innovation.

The resource inflows are consistent with VC reputation; however, it is not difficult to discover that resource outflows from backed entrepreneurial firms are inevitable. In a departure from earlier research on the blessing effect of $\mathrm{VC}$ reputation, in the following 
part, we will explain why this may be twisted into a curse effect, and explore the conditions under which negative consequences may be amplified.

Before uncovering the mystery, the true relationship between reputable $\mathrm{VC}$ and backed entrepreneurial firms should be taken into consideration. The "liability of newness" that causes entrepreneurial firms to be trapped in an extreme form of resource dependence has been widely acknowledged in extant research (Hallen and Eisenhardt 2012; Stinchcombe 1965). Consequently, obtaining resources through powerful outsider networks becomes the practical and almost only method. Similarly, VC-backed entrepreneurial firms rely on this reputable VC to acquire the otherwise inaccessible resources. Bound by this dependent relationship, entrepreneurial firms perform as low-power actors and wield little sway over the relationship and even the innovation activity (Katila et al. 2008; Pahnke et al. 2015). In short, the dependent relationship with VC may be an antecedent that turns VC reputation blessing into a curse, thus leading us to investigate $\mathrm{VC}$ reputation from a negative perspective-is there a resource outflow?

First, the dependence on reputable VC is likely to enable entrepreneurial firms to reduce their efforts on internal resource cultivation, and therefore block the development of innovation. Auty (1993) first puts forward the curse of resources, suggesting that resource abundance may be not a blessing but an adverse factor for economic development. It is resource dependence that causes the resource curse effect (Brunnschweiler and Bulte 2008; Gylfason and Zoega 2010). In the same way, entrepreneurial firms' dependence on VC reputation for resource acquisition is gradually self-reinforced and eventually develops into path dependence when resources are constrained. This induces entrepreneurial firms into a situation in which they are bound to satisfy the present rather than long-term benefit and will not strive for internal resource cultivation (Zhu and Li 2011), thus hindering innovation in the long run. The backed firm will be at a loss once the relationship ended. Thus, it could be seen that VC reputation may become a barrier to internal resource cultivation of entrepreneurial firms, and further to innovative outcomes.

Second, the positive resource inflows through reputable VC have been acknowledged in most prior research, whereas reputable VC as a powerful intermediary can also lead to negative resource outflows (Hernandez et al. 2015; Pahnke et al. 2015). Some research emphasizes that $\mathrm{VC}$-backed entrepreneurial firms may take risks of technology exposure to other firms via shared $\mathrm{VC}$, thus highlighting the downside of embeddedness-competitive leakage (Dushnitsky and Shaver 2010; Pahnke et al. 2015). This negative outflow increases especially when connecting with reputable VC, because with a broader network, there is more opportunity and motivation to perform as a matchmaker and promote resource flow (Kleinbaum and Stuart 2014). Further, VC-backed firms as low-power actors have little control over resources leaking in an unwanted direction, which has a negative bearing on entrepreneurs' motivation and confidence in success, as a result of which, this tends to reduce the effort of stimulating innovation.

Thus, when the effect of resource outflows exceeds that of resource inflows, the curse effect of VC reputation will be manifested. Accordingly, in contrary to H1a, we also argue that $\mathrm{VC}$ reputation may be not a blessing but a curse for entrepreneurial firm innovation and propose the hypothesis that: 
Hypothesis 1b: VC reputation will bring about the curse effect. In other words, VC reputation is negatively associated with entrepreneurial firm innovation.

\section{The contingent effect on the industrial nature of VC reputation}

As stated above, both blessing and curse effects of $\mathrm{VC}$ reputation are logically and practically possible, providing a potential explanation upon which the value of $\mathrm{VC}$ reputation is contingent. A growing body of evidence reveals the phenomenon that $\mathrm{VC}$ investments are gradually specialized in certain industries in which information and resources are circulated (Sorenson and Stuart 2001; Tang and Li 2018), and suggests that VC reputation is contingent upon industrial distance (Lee et al. 2011). Sorenson and Stuart (2001) point out, industrial distance "represents the level of dissimilarity between the VC firm's previous investment experiences and the industry classification of a given target company" (p. 1548), and more essentially, "captures the transferability of knowledge across domains (industries)" (p. 1565). Not surprisingly, in this increasingly professional society, resources like information and knowledge that backed firms need vary drastically across industries. When the industrial distance between $\mathrm{VC}$ and its backed firm is smaller, $\mathrm{VC}$ reputation and expertise have stronger pertinence and applicability for the firm; furthermore, the resources brought by VC reputation are easier to absorb and to be mobilized on the firm's behalf (Dimov and Clercq 2006; Hsu 2006). As it turns out, a small industrial distance, as a representation of knowledge similarity, will increase the blessing effect, and meanwhile, impair the curse effect. When it comes to a large industrial distance, the opposite occurs; it is manifested as a deteriorative curse effect. As such, we unpack the contingent value of $\mathrm{VC}$ high reputation on industrial distance, and propose the hypothesis:

Hypothesis 2: The curse effect of VC reputation on entrepreneurial firm innovation is deteriorated as the industrial distance between VC and the VC backed-firm increases.

Building on the idea that industrial distance may weaken the blessing effect but intensify the curse effect of $\mathrm{VC}$ reputation, we first divide VC reputation as a single construct, and following research from Bellavitis et al. (2014), specifically differentiate it into two dimensions: VC intra-industrial reputation and VC extra-industrial reputation, arguing that the curse effect may stem from $\mathrm{VC}$ extra-industrial reputation rather than intra-industrial reputation.

To begin, we take a simple example to illustrate what VC intra- and extra-industrial reputations are. As shown in Fig. 1, before the VC invests in firm F, it has successfully exited from firms $A, B, C, D$, and $\mathrm{E}$ in form of IPO, so we can count the entire VC reputation as 5. Further, firm $\mathrm{F}$ is within the technology industry, and firms $\mathrm{A}, \mathrm{B}$ and $\mathrm{C}$ are also in this industry. Therefore, we count $\mathrm{VC}$ intra-industrial reputation of firm $\mathrm{F}$ as 3. Yet, as firms D and E are not in the technology industry, this unmatched part is termed extra-industrial reputation, and counted as 2 .

We will first discuss the effect of VC intra- and extra-industrial reputations from the perspective of resource inflows. The limited research implies that although VC reputation plays a signaling role on certification, not all reputations are able to exert the 


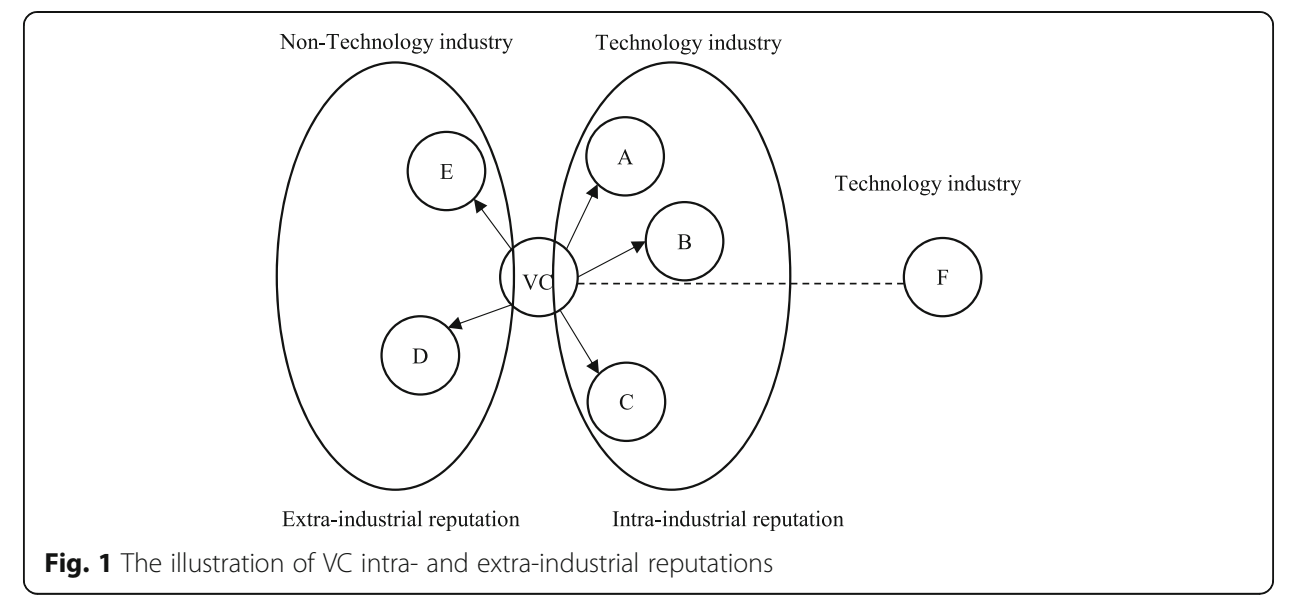

same effect (Gompers et al. 2009). Because industrial scope delimits the flow of private information (Sorenson and Stuart 2001), those VCs that focus on one or a few industries have greater selection ability with rich investment experiences and accumulated knowledge superiority (Gompers et al. 2005). Ultimately, VCs with specialization tend to outperform others and gain a higher reputation. Gompers et al. (2009) also emphasize the poor performance by generalists may be due to their poor selection ability within industries. Following this logic, we can infer that VC intra-industrial reputation which creates a resource inflow from resource holders in the effort of reducing information asymmetry to support backed firm innovation is of significance, while VC extra-industrial reputation has less or even no effect.

However, a better understanding of the resource inflows created by VC reputation may require a further exploration into whether they can be absorbed and then applied by the backed firms (Cohen and Levinthal 1990; Dushnitsky and Lenox 2005). It is the absorption process that promotes innovation (Cohen and Levinthal 1990; Kostopoulos et al. 2011; Zahra and George 2002). Extant research indicates that absorptive capacity is specific to a given domain; namely, that firms may exhibit a high absorptive capacity in given domains where they have expertise, but have little absorptive capacity in other domains with a lack of prior related knowledge (Dushnitsky and Lenox 2005; Veugelers 1997). By implication, VC with high intra-industrial reputation has a full understanding to create specific resource inflows for firms that have similar knowledge background to absorb, grasp and then capitalize. For example, Gompers et al. (2009) find that VC with expertise offers more significant value-added services. Chen, He, and Zhang (2017) state that some VCs with expertise regularly organize gatherings of entrepreneurs where they exchange the latest developments in the industry, promote technical communication and cooperation, thus facilitating the innovation of firms. However, lacking the prior knowledge of the industry in which the backed firm is located, VC with extra-industrial reputation just acts as a layman, and is unknowledgeable regarding the needs of the backed firms. Consequently, resource inflows are unable to be easily absorbed.

In the meantime, we will pay attention to the resource outflows caused by $\mathrm{VC}$ intraand extra-industrial reputations, respectively. As previously mentioned, entrepreneurial firms, backed by VC with a high intra-industrial reputation rather than extra-industrial, can have better access to more specific and easily-absorbed resources. Accordingly, the 
curse effect from resource outflows will be offset by a resource absorption and internalization process. However, when it comes to VC extra-industrial reputation, firms are more likely to suffer from resource outflows and the ignorance of internal resource cultivation without any compensatory resource inflows. More importantly, as most research emphasizes, $\mathrm{VC}$ has its own interests that do not align with or even diverge from those of entrepreneurial firms (Khurana 2002; Pollock 2004; Pollock et al. 2004), and this is particularly true for VCs with high extra-industrial reputation. Under these circumstances, entrepreneurial firms will be less empowered in making use of both resource inflows and outflows, as is made evident by real cases like OFO Bicycle Sharing, which used to be a leader in the field of the sharing economy but now has high levels of debt due to inconsistent interests and even conflicts between founders and VC.

Therefore, the comparison effects of resource inflows and outflows between VC intra- and extra-industrial reputations are summed up below (Table 1).

Then, we propose the hypotheses that:

Hypothesis 3a: VC intra-industrial reputation will bring about the blessing effect. In other words, VC intra-industrial reputation is positively associated with entrepreneurial firm innovation.

Hypothesis 3b: VC extra-industrial reputation will bring about the curse effect. In other words, VC extra-industrial reputation is negatively associated with entrepreneurial firm innovation.

By integrating the blessing and curse perspectives, we build a conceptual model (as shown in Fig. 2).

\section{Data, methodology and descriptive analysis}

\section{Data and the sample}

We study the effects of VC reputation on entrepreneurial firms' innovation in China's VC industry and the New OTC Market, an ideal context for two reasons. First, the New OTC Market provides a platform to promote the development of entrepreneurial firms with great innovation and developmental potential. Those listed firms characterized as innovative start-ups allow for an analysis of firm innovation performance. Second, the New OTC Market is the third national stock exchange. The significant difference from other forms of stock exchange (e.g., the Shanghai and Shenzhen Stock

Table 1 The comparison effect of VC intra- and extra-industrial reputations

\begin{tabular}{llll}
\hline VC reputation & Resource inflows & Resource outflows & Result \\
\hline Intra- & Strong & Weak & $E_{\text {in }}>E_{\text {out }}$ \\
industrial & $\begin{array}{l}\text { Strong signaling role; } \\
\text { Strong resource role (can be }\end{array}$ & $\begin{array}{l}\text { Internalizing resources by absorbing; Resource } \\
\text { outflows offset by absorptive resource inflows; }\end{array}$ & Blessing effect \\
& easily absorbed); & & \\
Extra- & Weak & Strong & $E_{\text {out }}>E_{\text {in }}$ \\
industrial & Weak signaling role; & Ignorance of internal resources cultivation; & Curse effect \\
& Strong resource role & Resource outflows more than offset by poorly & \\
& (but poorly absorbed); & absorptive resource inflows. & \\
\hline
\end{tabular}






Fig. 2 Conceptual model

Exchanges) is that the investment structure is dominated by institutional investors (mostly VC) with the main purpose of promoting firms' growth, rather than small-medium and even individual investors looking for trading or speculation. Therefore, the New OTC Market and the involved VC investors create an ideal context and allow for our research on the relationship between VC reputation and entrepreneurial firm innovation.

We compile our data from the Wind databases and the State Administration of Industry and Commerce (SAIC) information query system. The Wind database, a leading data services provider in China, offers extensive statistics with global, domestic and industry coverage. Also, the Wind database provides the financial statistics and basic information regarding firms in the New OTC Market. The detailed data on the investment deals of $\mathrm{VC}$ is shown, providing access to gain more information about $\mathrm{VC}$ from the SAIC information query system. After excluding inconsistent or missing data, we get 752 firms with VC participation in the New OTC Market and a total of 1553 observations from 2008 to 2016. Table 2 reports the sample distribution based on year and the industry classification of the Wind database.

Table 2 Sample distribution

\begin{tabular}{|c|c|c|c|c|c|}
\hline Industry & Sample & Percentage & Year & Sample & Percentage \\
\hline Information and technology & 599 & $38.57 \%$ & 2008 & 6 & $0.39 \%$ \\
\hline Industry & 359 & $23.12 \%$ & 2009 & 13 & $0.84 \%$ \\
\hline Consumer discretionary & 201 & $12.94 \%$ & 2010 & 17 & $1.09 \%$ \\
\hline Materials & 164 & $10.56 \%$ & 2011 & 29 & $1.87 \%$ \\
\hline Health care & 112 & $7.21 \%$ & 2012 & 47 & $3.03 \%$ \\
\hline Daily consumption & 73 & $4.7 \%$ & 2013 & 93 & $5.99 \%$ \\
\hline Energy & 17 & $1.09 \%$ & 2014 & 175 & $11.27 \%$ \\
\hline Public utilities & 13 & $0.84 \%$ & 2015 & 443 & $28.53 \%$ \\
\hline Finance & 6 & $0.39 \%$ & 2016 & 730 & $47.01 \%$ \\
\hline Telecommunication service & 6 & $0.39 \%$ & & & \\
\hline Real estate & 3 & $0.19 \%$ & & & \\
\hline Total & 1553 & $100 \%$ & Total & 1553 & $100 \%$ \\
\hline
\end{tabular}

Notes. Based on the industry classification of Wind database 
Variable

Dependent variable

Total factor productivity We use Total Factor Productivity (Tfp) as the dependent variable to account for entrepreneur firm innovation. According to Smith (2014), patents are commonly used to capture explicit rather than implicit aspects of innovation, while Tfp can capture both aspects, making it a more appropriate indicator. We follow this literature and Tfp is calculated by the LP method (Levinsohn and Petrin 2003). Considering the hysteresis effect of innovation, we use the one-year lagged $T f p\left(T f p_{t+1}\right)$.

\section{Independent variable}

VCrep Following most extant research (Dimov and Milanov 2010; Gu and Lu 2014; Park and Steensma 2012), the IPO event is the most successful and significant mark of a VC's past performance, and accordingly, the number of IPOs before the focal year has been widely used as a proxy for a VC's reputation (VCrep).

IntraRep and ExtraRep Following Bellavitis et al. (2014) and Wang et al. (2018), we divide VCrep into two variables by industry dimension, that is VC intra-industrial reputation (IntraRep) and extra-industrial reputation (ExtraRep). IntraRep captures the similarity between the prior successful investment of VC and its backed firm, measured as the number of IPOs occurring in the backed firm's industry before the focal year, while ExtraRep is the opposite, calculated as the number of IPOs not taking place in the backed firm's industry before the focal year. The industry classification of the Wind database is used to classify the backed firm and distinguish IntraRep and ExtraRep.

In the case of entrepreneurial firms backed by two or more VCs, the average value is used. The following variables in this case are treated in the same way.

\section{Moderating variable}

Industrial distance Following Sorenson and Stuart (2001), industrial distance (ID) is defined as the degree of differentiation in the industrial scope between VC's prior investments and the backed entrepreneurial firm in the focal year, calculated by one minus the ratio of the number of targeted industry firms that $\mathrm{VC}$ backed before the current investment, divided by the number of all backed firms. In line with this measurement, industrial distance is varied from " 0 " to " 1 ." For example, imagine that there is an investment deal between $\mathrm{VC}$ and a firm operating in the technology industry. Before the VC invests in this firm, it has built investment relationships with five firms, among which three firms operate in the technology industry and two firms operate in other industries. Then, the industrial distance is 0.4 , calculated as dividing 2 by 5 . Besides, the two extreme cases are respectively when all prior investments of $\mathrm{VC}$ fall in the backed firm's industry (denoted as "0") and when none of VC's prior investments fall in the backed firm's industry (denoted as “1”). Thus, the larger the value, the greater the degree of differentiation. 


\section{Control variable}

We control a series of variables relating to VCs and their backed entrepreneurial firms. First, to control for the variations of VCs and their investment deals, we control for the number of VCs $(\mathrm{Num} V \mathrm{C})$ joining together to take an equity stake in an investment, which is defined as VC syndication when the number is two or more (Tian 2012). We also control for the age of VC (VCAge). VCAge is the number of years since the VC was registered. Second, following previous studies (Giannetti et al. 2015; Tian 2012), we control for a number of firm characteristics that may affect $T f p$, including firm age (Age), state-owned enterprises $(S O E)$, return on assets $(R O A)$, firm size (lnSize) and the expenses for material and other inputs $(\operatorname{lnm})$. Age is the number of years since the backed firm was registered. $S O E$ equals "1" if the backed firm is owned by the government, "0" otherwise. lnSize is calculated by the logarithm of firm asset, and lnm is calculated by the logarithm of the expenses for material and other inputs of the firm. Third, apart from these variables of VCs and their backed entrepreneurial firms, some macro-level factors should be taken into consideration, including the growth rate of industry (IGrowth) and the GDP of the city $(\ln G D P)$. IGrowth is the growth rate of the industry in which the VC-backed entrepreneurial firm operates. In assigning backed firms to industries, we use the industry classification of the Wind database. $\ln G D P$ is calculated by the logarithm of GDP in the city where the VC-backed entrepreneurial firm is located. Finally, industry and year fixed effects are included.

\section{Model specification}

We employ ordinary least square (OLS) regressions to investigate the effect of VC reputation on backed firm innovation and test our hypotheses. The model specification can be expressed as:

$$
T f p_{t+1}=\beta_{0}+\beta_{1} \text { VCrep }_{t}+\beta_{2} I D_{t}+\beta_{3} \operatorname{VCRep}_{t} \times I D_{t}+\beta_{i} \text { Controls }_{t}+\varepsilon .
$$

Specifically, the model specification in which the effect of VC intra- and extra-industrial reputation will be estimated can be expressed as:

$$
T f p_{t+1}=\beta_{0}+\beta_{1} \text { IntraRep }_{t}+\beta_{2} \text { ExtraRep }_{t}+\beta_{i} \text { Controls }_{t}+\varepsilon
$$

In these two specifications, we use the lagged value of Tfp in the year following the focal year $(t+1)$. Other variables are all measured in the focal year $(t)$. Additionally, we multiply $T f p_{t+1}$ by 100 to reduce the scale to a low level (Deng and Wang 2016).

\section{Results}

Table 3 reports the descriptive statistics and correlation coefficients of all variables involved. To remove the concern of multicollinearity, the variance inflation factor (VIF) values are calculated. The average VIF values in all models are below 1.4 (below the traditional threshold of 6), and all VIF values of the variables involved are below 2.9 (below the traditional threshold of 10) (Colombo et al. 2015; McDonald and Moffitt 1980).

Table 4 indicates the OLS regression results of $\mathrm{H} 1, \mathrm{H} 2$ and $\mathrm{H} 3$. In Model 1, we enter all control variables. Model 2 includes $V C r e p$ as the main explanatory variable to test $\mathrm{H} 1 \mathrm{a}$ and $\mathrm{H} 1 \mathrm{~b}$. The result reveals that VCrep has a significantly negative but not positive coefficient $(\beta=-0.084, p<0.05)$, and thus H1b is supported, while H1a 


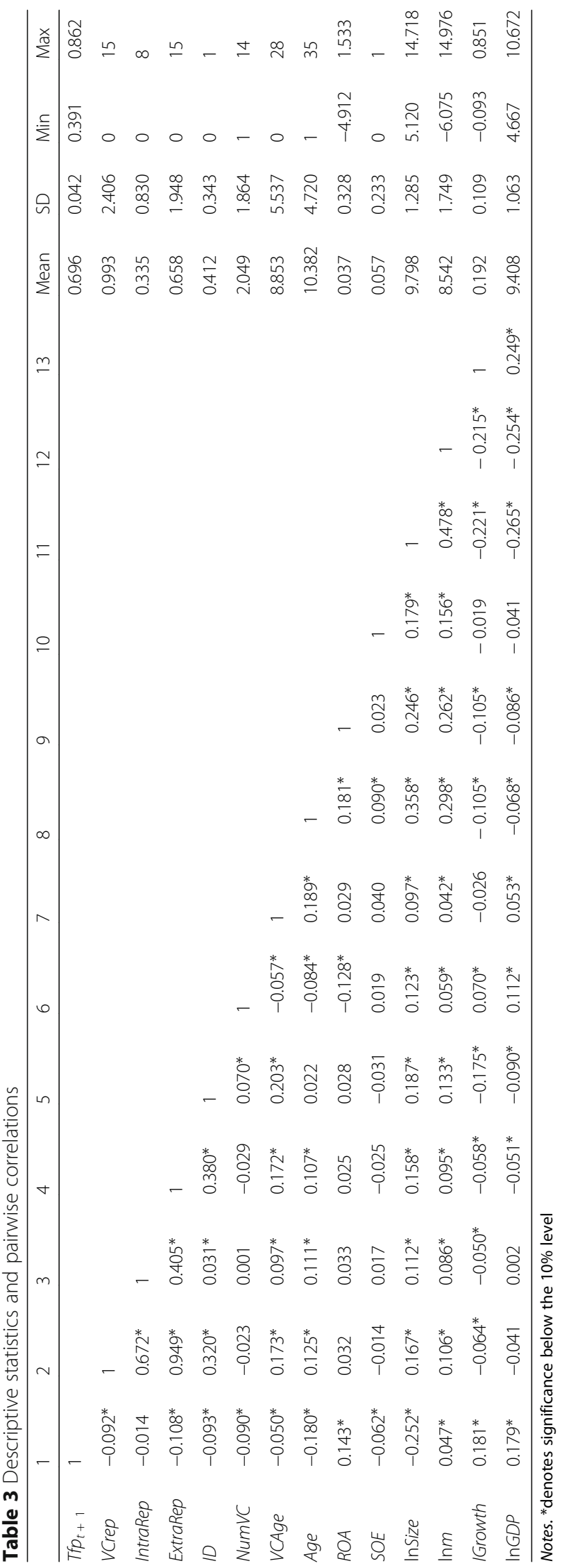


Table 4 Regression results of $\mathrm{H} 1, \mathrm{H} 2$ and $\mathrm{H} 3$

\begin{tabular}{|c|c|c|c|c|}
\hline & \multicolumn{4}{|l|}{$T f p_{t+1}$} \\
\hline & Model 1 & Model 2 & Model 3 & Model 4 \\
\hline \multirow[t]{2}{*}{ VCrep } & & $-0.084^{* *}$ & $0.450^{* *}$ & \\
\hline & & $(0.038)$ & $(0.179)$ & \\
\hline \multirow[t]{2}{*}{ VCrep $\times \mathbb{I D}$} & & & $-0.684^{* * *}$ & \\
\hline & & & $(0.228)$ & \\
\hline \multirow[t]{2}{*}{ ID } & & & 0.135 & \\
\hline & & & $(0.316)$ & \\
\hline \multirow[t]{2}{*}{ IntraRep } & & & & $0.203^{*}$ \\
\hline & & & & $(0.116)$ \\
\hline \multirow[t]{2}{*}{ ExtraRep } & & & & $-0.171^{* * *}$ \\
\hline & & & & $(0.051)$ \\
\hline \multirow[t]{2}{*}{ NumVC } & $-0.143^{* * *}$ & $-0.145^{* * *}$ & $-0.143^{* * *}$ & $-0.147^{* * *}$ \\
\hline & $(0.049)$ & $(0.049)$ & $(0.050)$ & $(0.049)$ \\
\hline \multirow[t]{2}{*}{ VCAge } & 0.007 & 0.013 & 0.022 & 0.014 \\
\hline & $(0.016)$ & $(0.016)$ & $(0.018)$ & $(0.016)$ \\
\hline \multirow[t]{2}{*}{ Age } & $-0.114^{* * *}$ & $-0.112^{* * *}$ & $-0.127^{* * *}$ & $-0.114^{* * *}$ \\
\hline & $(0.020)$ & $(0.020)$ & $(0.022)$ & $(0.020)$ \\
\hline \multirow[t]{2}{*}{$R O A$} & $2.372^{* * *}$ & $2.367^{* * *}$ & $2.348^{* * *}$ & $2.363^{* * *}$ \\
\hline & $(0.282)$ & $(0.282)$ & $(0.320)$ & $(0.282)$ \\
\hline \multirow[t]{2}{*}{ SOE } & -0.081 & -0.111 & -0.189 & -0.137 \\
\hline & $(0.387)$ & $(0.387)$ & $(0.390)$ & $(0.386)$ \\
\hline \multirow[t]{2}{*}{ InSize } & $-2.061^{* * *}$ & $-2.037^{* * *}$ & $-2.127^{* * *}$ & $-2.030^{* * *}$ \\
\hline & $(0.115)$ & $(0.115)$ & $(0.124)$ & $(0.115)$ \\
\hline \multirow[t]{2}{*}{$\ln m$} & $1.494^{* * *}$ & $1.489 * * *$ & $1.497^{* * *}$ & $1.485^{* * *}$ \\
\hline & $(0.080)$ & $(0.080)$ & $(0.083)$ & $(0.080)$ \\
\hline \multirow[t]{2}{*}{ IGrowth } & $3.031^{* * *}$ & $2.873^{* * *}$ & $2.661^{* * *}$ & $2.930^{* * *}$ \\
\hline & $(0.933)$ & $(0.934)$ & $(1.028)$ & $(0.933)$ \\
\hline \multirow[t]{2}{*}{$\ln G D P$} & $0.418^{* * *}$ & $0.417^{* * *}$ & $0.327^{* * *}$ & $0.409^{* * *}$ \\
\hline & $(0.091)$ & $(0.091)$ & $(0.097)$ & $(0.091)$ \\
\hline Industry dummies & Included & Included & Included & Included \\
\hline Year dummies & Included & Included & Included & Included \\
\hline \multirow[t]{2}{*}{ Constant } & $71.830^{* * *}$ & $71.700^{* * *}$ & $73.089 * * *$ & $71.587^{* * *}$ \\
\hline & $(1.862)$ & $(1.860)$ & $(1.890)$ & $(1.857)$ \\
\hline$N$ & 1553 & 1553 & 1328 & 1553 \\
\hline$F$ & 40.20 & 38.52 & 30.37 & 37.16 \\
\hline$R^{2}$ & 0.333 & 0.335 & 0.339 & 0.338 \\
\hline
\end{tabular}

Notes. (1) Dependent variable is $T f p_{t+1}$. (2) The regression model is OLS. (3) $t$-statistics is reported in the parentheses. (4) ${ }^{*}$ denotes significance at the $10 \%$ level. ${ }^{* *}$ denotes significance at the $5 \%$ level. ${ }^{* *}$ denotes significance at the $1 \%$ level

is not supported. The conclusion can be drawn that VC reputation is not a blessing but a curse for entrepreneurial firm innovation, since resource outflow exceeds resource inflow. To test the moderating effect, the moderating variable, $I D$, and the interaction term, $V C r e p \times I D$, are included in Model 3. We find that the coefficient of this interaction term is negative $(\beta=-0.684)$ and highly significant $(p<0.01)$, suggesting that the larger $I D$ is, the more negative effect of VCrep on $T f p_{t+1}$ imposes, thus supporting H2. Finally, 
we argue that the curse effect of VCrep is mainly from ExtraRep rather than IntraRep as H3a and H3b predict, and then introduce IntraRep and ExtraRep into Model 4 to test this. As the regression result shows, IntraRep has a surprisingly positive and significant coefficient $(\beta=0.203, p<0.1)$, while the coefficient of ExtraRep remains significantly negative $(\beta=-0.171, p<0.01)$, which supports $\mathrm{H} 3 \mathrm{a}$ and $\mathrm{H} 3 \mathrm{~b}$.

In addition to constructing the interaction term of the moderating variable and the explanatory variable, we use subgroup regression with two methods of grouping to verify the moderating effect of $I D$. The subgroup regression results of $\mathrm{H} 2$ are shown in Table 5. First, we divide the whole sample by the 1st quartile (" 0 ") and the 3rd quartile ("0.723") of ID. Then, three subgroups ensue. They are Low ID group (ID =0), Median ID group $(0<I D \leq 0.723)$ and High ID group $(I D>0.723)$. As is shown in Models 1,2 and 3, VCrep has a significantly positive effect $(\beta=0.702, p<0.05)$ in Low ID group, a positive but not significant effect $(\beta=0.051$,

Table 5 Subgroup regression results of $\mathrm{H} 2$

\begin{tabular}{|c|c|c|c|c|}
\hline \multirow[t]{3}{*}{ Subgroup } & \multicolumn{4}{|l|}{$T f p_{t+1}$} \\
\hline & Model 1 & Model 2 & Model 3 & Model 4 \\
\hline & Low ID/ID = 0 & Median ID & High ID & $\mathrm{ID}=1$ \\
\hline \multirow[t]{2}{*}{ VCrep } & $0.702^{* *}$ & 0.051 & $-0.162^{* * *}$ & $-0.566^{* * *}$ \\
\hline & $(0.316)$ & $(0.067)$ & $(0.050)$ & $(0.193)$ \\
\hline \multirow[t]{2}{*}{ NumVC } & -0.142 & $-0.207^{* * *}$ & -0.060 & -0.236 \\
\hline & $(0.142)$ & $(0.065)$ & $(0.094)$ & $(0.385)$ \\
\hline \multirow[t]{2}{*}{ VCAge } & $0.064^{* *}$ & 0.036 & 0.002 & $0.170^{*}$ \\
\hline & $(0.032)$ & $(0.029)$ & $(0.027)$ & $(0.093)$ \\
\hline \multirow[t]{2}{*}{ Age } & $-0.160^{* * *}$ & $-0.148^{* * *}$ & $-0.080^{* *}$ & $-0.188^{*}$ \\
\hline & $(0.043)$ & $(0.035)$ & $(0.031)$ & $(0.094)$ \\
\hline \multirow[t]{2}{*}{$R O A$} & $2.903^{* * *}$ & $1.796^{* * *}$ & $2.181^{* * *}$ & 2.297 \\
\hline & $(0.456)$ & $(0.578)$ & $(0.471)$ & $(1.510)$ \\
\hline \multirow[t]{2}{*}{ SOE } & $-1.274^{*}$ & -0.071 & 0.976 & 1.274 \\
\hline & $(0.693)$ & $(0.636)$ & $(0.709)$ & $(2.005)$ \\
\hline \multirow[t]{2}{*}{ InSize } & $-2.092^{* * *}$ & $-2.120^{* * *}$ & $-1.806^{* * *}$ & $-1.945^{* * *}$ \\
\hline & $(0.267)$ & $(0.188)$ & $(0.173)$ & $(0.572)$ \\
\hline \multirow[t]{2}{*}{$\ln m$} & $1.108^{* * *}$ & $1.832^{* * *}$ & $1.348^{* * *}$ & $1.522^{* * *}$ \\
\hline & $(0.177)$ & $(0.126)$ & $(0.128)$ & $(0.422)$ \\
\hline \multirow[t]{2}{*}{ IGrowth } & 3.022 & 1.389 & $3.497^{* *}$ & -11.993 \\
\hline & $(2.040)$ & $(1.563)$ & $(1.433)$ & $(7.384)$ \\
\hline \multirow[t]{2}{*}{$\ln G D P$} & 0.002 & $0.732^{* * *}$ & $0.410^{* * *}$ & 0.697 \\
\hline & $(0.190)$ & $(0.165)$ & $(0.138)$ & $(0.473)$ \\
\hline Industry dummies & Included & Included & Included & Included \\
\hline Year dummies & Included & Included & Included & Included \\
\hline \multirow[t]{2}{*}{ Constant } & $78.759^{* * *}$ & $73.450^{* * *}$ & $73.364^{* * *}$ & $75.557^{* * *}$ \\
\hline & (3.076) & $(3.801)$ & $(2.573)$ & $(7.019)$ \\
\hline N & 450 & 542 & 561 & 65 \\
\hline$F$ & 8.84 & 17.45 & 19.34 & 3.74 \\
\hline$R^{2}$ & 0.292 & 0.388 & 0.405 & 0.594 \\
\hline
\end{tabular}

Notes. (1) Dependent variable is $T f p_{t+1}$. (2) The regression model is OLS. (3) $t$-statistics is reported in the parentheses. (4) ${ }^{*}$ denotes significance at the $10 \%$ level. ${ }^{* *}$ denotes significance at the $5 \%$ level. ${ }^{* * *}$ denotes significance at the $1 \%$ level 
$p>0.1)$ in Median ID group, and a significantly negative effect $(\beta=-0.162, p<0.01)$ in High ID group. Additionally, the difference effect of VCrep between Low ID group and High ID group is supported by $Z$-test $(Z=2.701, p<0.01)$. Second, the extreme cases are taken into account, one of which is that all prior investments of $\mathrm{VC}$ fall in the backed firm's industry ( $I D=0$ group), the other one of which is that no prior investments of VC fall in the backed firm's industry ( $I D=1$ group). The result in Model 4 indicates a significantly negative effect of VCrep in group of $I D=1(\beta=-0.566, p<0.01)$. The great difference of these two extreme cases is also supported by $Z$-test $(Z=3.424, p<0.01)$. As expected, the negative effect in the group of $I D=1$ is more than that in the group of High ID with $Z$-test supporting $(Z=2.026, p<0.05)$. As such, $\mathrm{H} 2$ is strongly supported.

\section{Further tests}

Our regression results provide evidence for H1b, H2, H3a and H3b. Given the curse effect of VC reputation and the varied roles of VC intra- and extra-industrial reputations, it is of great necessity to further investigate what types of VC best foster firm innovation, and how such effects vary across time.

\section{What types of VC are best for entrepreneurial firm innovation?}

To answer the question on the varied effects among different types of $\mathrm{VC}$, a comparison among subgroup regression results is conducted. The median value of VC intra-industrial reputation is used to divide it into the low and the high elements; the same is done for VC extra-industrial reputation. Subsequently, according to these two dimensions of intra- and extra-industrial reputation, four types of VC are formed. As shown in Fig. 3, there are (1) Low IntraRep \& Low ExtraRep group; (2) High IntraRep \& High ExtraRep group; (3) High IntraRep \& Low ExtraRep group; and (4) Low IntraRep \& High ExtraRep group. Again, the OLS regression is employed to test the effects of VCrep in these four subgroups.

Table 6 shows the results. We find a significantly positive effect $(\beta=1.711, p<0.01)$ of High IntraRep \& Low ExtraRep group in Model 3, and a significantly opposite effect

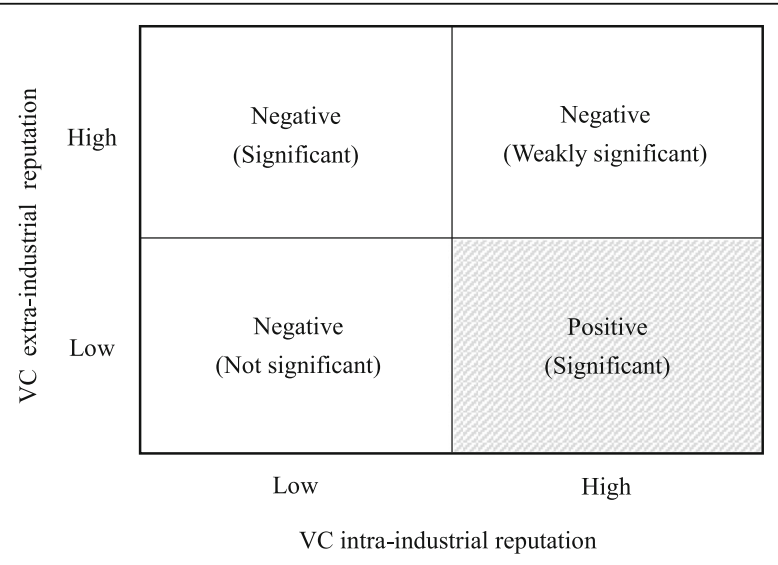

Fig. 3 The varied effects on backed firm innovation of four types of VC 
Table 6 Subgroup with VC types (divided by median)

\begin{tabular}{|c|c|c|c|c|}
\hline \multirow[t]{3}{*}{ Subgroup } & \multicolumn{4}{|l|}{$T f p_{t+1}$} \\
\hline & Model 1 & Model 2 & Model 3 & Model 4 \\
\hline & $\begin{array}{l}\text { Low IntraRep \& Low } \\
\text { ExtraRep }\end{array}$ & $\begin{array}{l}\text { High IntraRep \& High } \\
\text { ExtraRep }\end{array}$ & $\begin{array}{l}\text { High IntraRep \& Low } \\
\text { ExtraRep }\end{array}$ & $\begin{array}{l}\text { Low IntraRep \& High } \\
\text { ExtraRep }\end{array}$ \\
\hline \multirow[t]{2}{*}{ VCrep } & - & -0.056 & $1.711^{* * *}$ & $-0.382^{* * *}$ \\
\hline & & $(0.071)$ & $(0.503)$ & $(0.129)$ \\
\hline \multirow[t]{2}{*}{ NumVC } & -0.026 & -0.149 & -0.157 & $-0.402^{* * *}$ \\
\hline & $(0.092)$ & $(0.120)$ & $(0.116)$ & $(0.104)$ \\
\hline \multirow[t]{2}{*}{ VCAge } & $0.039^{*}$ & 0.007 & -0.024 & 0.010 \\
\hline & $(0.023)$ & $(0.071)$ & $(0.037)$ & $(0.057)$ \\
\hline \multirow[t]{2}{*}{ Age } & $-0.108^{* * *}$ & -0.092 & $-0.092^{*}$ & $-0.173^{* * *}$ \\
\hline & $(0.027)$ & $(0.057)$ & $(0.048)$ & $(0.058)$ \\
\hline \multirow[t]{2}{*}{$R O A$} & $2.443^{* * *}$ & $1.844^{*}$ & $3.005^{* *}$ & $2.712^{* *}$ \\
\hline & $(0.326)$ & $(1.063)$ & $(1.408)$ & $(1.147)$ \\
\hline \multirow[t]{2}{*}{$S O E$} & 0.016 & 0.908 & $-1.206^{*}$ & $3.067^{* *}$ \\
\hline & $(0.557)$ & $(1.171)$ & $(0.722)$ & $(1.456)$ \\
\hline \multirow[t]{2}{*}{ InSize } & $-1.962^{* * *}$ & $-1.867^{* * *}$ & $-2.223^{* * *}$ & $-2.035^{* * *}$ \\
\hline & $(0.152)$ & $(0.317)$ & $(0.336)$ & $(0.309)$ \\
\hline \multirow[t]{2}{*}{$\ln m$} & $1.477^{* * *}$ & $1.378^{* * *}$ & $1.475^{* * *}$ & $1.636^{* * *}$ \\
\hline & $(0.109)$ & $(0.175)$ & $(0.236)$ & $(0.242)$ \\
\hline \multirow[t]{2}{*}{ IGrowth } & $3.370^{* * *}$ & 2.054 & 2.013 & 2.201 \\
\hline & $(1.264)$ & $(2.227)$ & $(2.142)$ & (3.204) \\
\hline \multirow[t]{2}{*}{$\ln G D P$} & $0.414^{* * *}$ & 0.252 & $0.648^{* *}$ & 0.422 \\
\hline & $(0.119)$ & $(0.237)$ & $(0.296)$ & $(0.256)$ \\
\hline Industry dummies & Included & Included & Included & Included \\
\hline Year dummies & Included & Included & Included & Included \\
\hline \multirow[t]{2}{*}{ Constant } & $72.152^{* * *}$ & $77.863^{* * *}$ & $69.056^{* * *}$ & $75.283^{* * *}$ \\
\hline & (3.013) & (3.868) & (3.936) & $(4.176)$ \\
\hline N & 939 & 182 & 236 & 196 \\
\hline$F$ & 23.75 & 7.53 & 5.42 & 9.85 \\
\hline$R^{2}$ & 0.329 & 0.422 & 0.335 & 0.500 \\
\hline
\end{tabular}

Notes. (1) Dependent variable is $T f p_{t+1}$. (2) The regression model is OLS. (3) $t$-statistics is reported in the parentheses. (4) *denotes significance at the $10 \%$ level. ${ }^{*}$ denotes significance at the $5 \%$ level. ${ }^{* *}$ denotes significance at the $1 \%$ level

$(\beta=-0.382, p<0.01)$ of Low IntraRep \& High ExtraRep group in Model 4. Again, such difference is supported by a significant $Z$-value $(Z=4.031, p<0.01)$. In other words, $\mathrm{VC}$ with high intra-industrial reputation and low extra-industrial reputation is the most conducive to nurturing entrepreneurial firm innovation, while VC with low intra-industrial reputation and high extra-industrial reputation is the most adverse. In addition, the coefficient of VCrep in Model 1 is missing since all values of VCrep are equal to " 0 " and lead to its lack of variance.

Moreover, we employ another criterion, the value of mean, to divide VC intra- and extra-industrial reputations into the low or high value aspects. Similarly, four types of $\mathrm{VC}$ are formed. The subgroup regression results shown in Table 7 are similar to those in Table 6, suggesting a robust conclusion (shown in Fig. 3). 
Table 7 Subgroup with VC types (divided by mean)

\begin{tabular}{|c|c|c|c|c|}
\hline \multirow[t]{3}{*}{ Subgroup } & \multicolumn{4}{|l|}{$T f p_{t+1}$} \\
\hline & Model 1 & Model 2 & Model 3 & Model 4 \\
\hline & $\begin{array}{l}\text { Low IntraRep \& Low } \\
\text { ExtraRep }\end{array}$ & $\begin{array}{l}\text { High IntraRep \& High } \\
\text { ExtraRep }\end{array}$ & $\begin{array}{l}\text { High IntraRep \& Low } \\
\text { ExtraRep }\end{array}$ & $\begin{array}{l}\text { Low IntraRep \& High } \\
\text { ExtraRep }\end{array}$ \\
\hline \multirow[t]{2}{*}{ VCrep } & -1.115 & $-0.161^{* *}$ & $1.530^{* * *}$ & $-0.321^{* *}$ \\
\hline & $(1.202)$ & $(0.074)$ & $(0.551)$ & $(0.137)$ \\
\hline Controls & Included & Included & Included & Included \\
\hline \multirow[t]{2}{*}{ Constant } & $72.400^{* * *}$ & $83.069^{* * *}$ & $70.192^{* * *}$ & $77.022^{* * *}$ \\
\hline & $(2.934)$ & $(4.301)$ & (3.999) & $(4.492)$ \\
\hline N & 1003 & 141 & 241 & 168 \\
\hline$F$ & 24.55 & 7.62 & 6.04 & 9.24 \\
\hline$R^{2}$ & 0.333 & 0.496 & 0.355 & 0.527 \\
\hline
\end{tabular}

Notes. (1) Dependent variable is $T f p_{t+1}$. (2) The regression model is OLS. (3) $t$-statistics is reported in the parentheses. (4) ${ }^{* *}$ denotes significance at the $5 \%$ level. ${ }^{* * *}$ denotes significance at the $1 \%$ level

\section{How does the effect vary over time?}

Our results reveal the complicated roles of different $\mathrm{VC}$ reputations in cultivating entrepreneurial firm innovation. However, the transaction or dependency relationship between VC and a backed firm is built on the foundation of the investment deal, and inevitably, changes as the backed firm gradually develops and even ends after the exit of VC. These practical contexts offer a research insight that the time dimension needs to be taken into account, raising the question of whether the effects of VC reputation are bound temporally, and how the effect varies over time.

To answer this question, our research constructs a series of lagged dependent variables, namely $T f p_{t}, T f p_{t+1}, T f p_{t+2}, T f p_{t+3}$, and $T f p_{t+4}$, and examines the effect of VCrep, IntraRep, and ExtraRep on those variables by OLS regression respectively. Table 8 reports the regression results. We can see the blessing effect of VC intra-industrial reputation and the curse effect of extra-industrial reputation can have a prolonged impact over years, the combination of which determines the overall effect of VC reputation. The results also indicate that our findings are robust. Visually, Fig. 4 depicts the line chart of the varied effect over time.

\section{Robustness tests}

To ensure the robustness of our findings, we conduct various sets of tests by different measures. First, we employ another alternative proxy of $\mathrm{VC}$ reputation, that is VC investment $(V C I n v)$, calculated by the number of prior investment deals of $\mathrm{VC}$ before the focal year. Accordingly, we construct two variables: VC intra-industrial investment (IntraInv) and VC extra-industrial investment (ExtraInv). Table 9 reports the regression results of the examination of $\mathrm{H} 1, \mathrm{H} 2$ and $\mathrm{H} 3$. Then, employing the same methods (the value of median as demarcation point), we form four subgroups. Table 10 reports the results of the varied effect of VCInv in different subgroups. The results consistently support H1b, H2, H3a, H3b and the further test.

Second, we use another industry classification standard to divide VC reputation into intra- and extra-industrial reputations. VC reputation is viewed as an overall concept in previous research. However, for the first time, we open the black box of this concept via the industrial dimension. As a result, the choice of the industry classification 


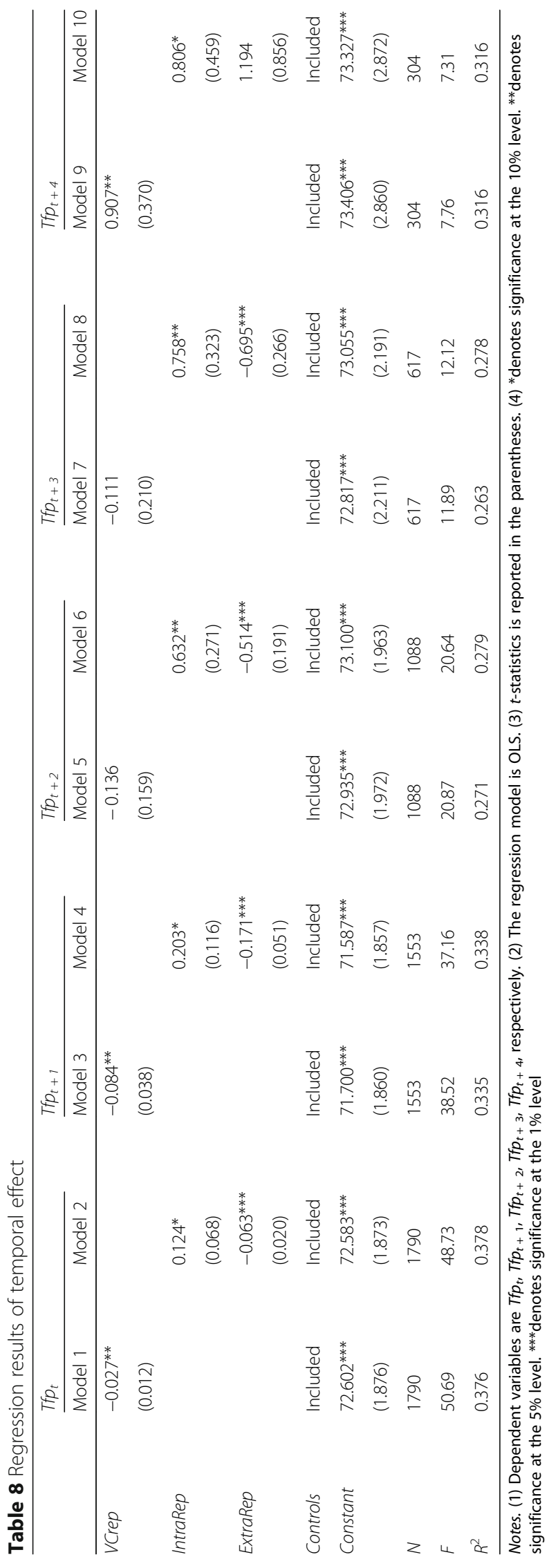




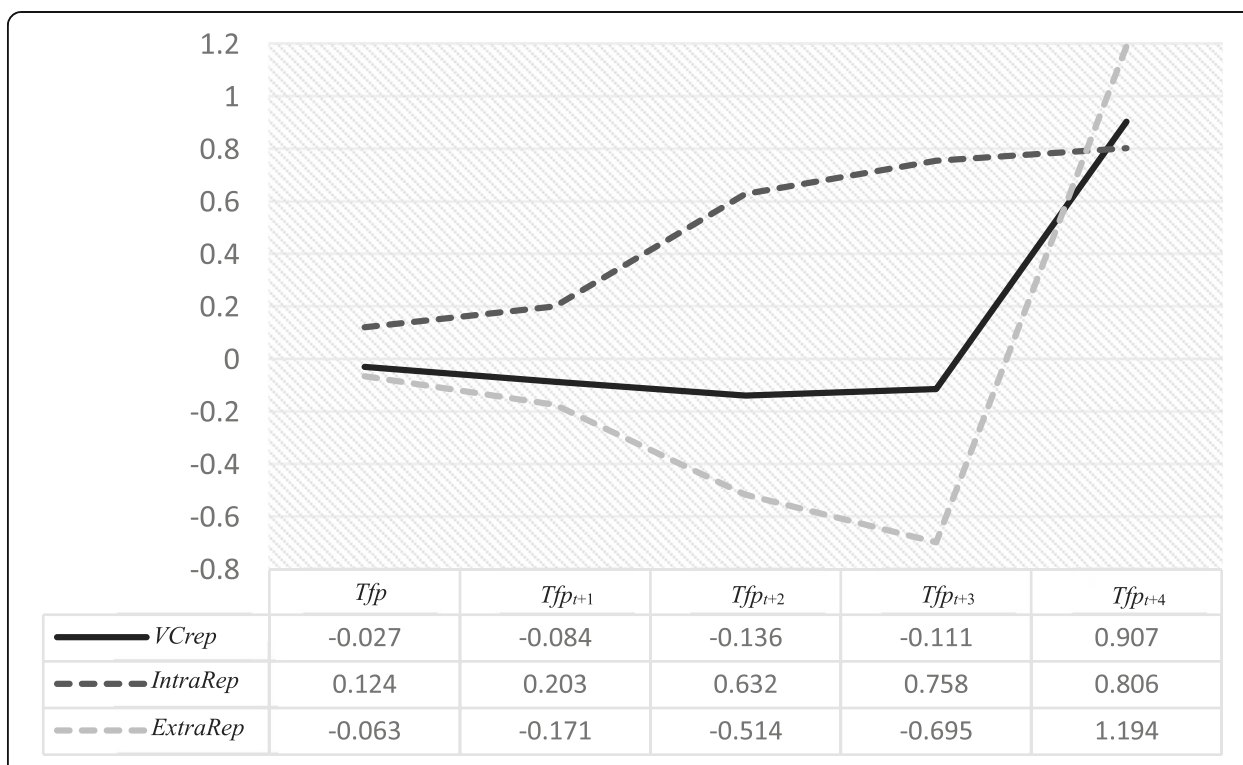

Fig. 4 The varied effects over time

standard is a great challenge. The above variable constructions and regression results are all based on the industry classification of the Wind database, including information and technology, industry, consumer discretionary, materials, health care, daily consumption, public utilities, finance, telecommunication services, and real estate industries (11 industries in total). To remove the concern of different industry classification standards and support the robustness of our findings, we employ another classification standard from the China Securities Regulatory Commission (CSRC), a more detailed classification standard including 76 industries. Based on this new standard, we construct the new variables which are IntraRep_c and ExtraRep_c. Also, four subgroups related to VC type are formed by these two new variables. Again, an OLS regression is employed. Table 11 reports the results. Even though the industry classification standard is altered, the findings that VC intra-industrial reputation is a blessing to entrepreneurial firm innovation but extra-industrial reputation acts as a curse remain robust (shown in Model 1). In addition, the results of Models 2-5 still support that VC with high intra-industrial reputation and low extra-industrial reputation has significant bearing in fostering backed-firm innovation.

Additionally, in the robustness test, we also examine the time-varied effects of $V C \operatorname{In} v$, IntraInv, ExtraInv, IntraRep_c, and ExtraRep_c. The regression results are shown in Table 12, and support a robust time-varied effect.

Third, we calculate dependent variable Tfp by the industry-classified measurement, as the previous measurement of Tfp used the LP method and is based on samples from all industries. Further, we divide the sample into 11 subgroups in terms of the Wind industry classification, and again, use the same LP method of calculation, respectively. The values of industry-classified $T f p\left(T f p_{-} w\right)$ are also calculated. Furthermore, we use the one-year lagged $T f p_{-} w\left(T f p_{-} w_{t+1}\right)$ as the dependent variable to perform the robustness test. Table 13 indicates the results, and $\mathrm{H} 1 \mathrm{~b}, \mathrm{H} 2, \mathrm{H} 3 \mathrm{a}$ and $\mathrm{H} 3 \mathrm{~b}$ are still supported.

Fourth, we use OLS regression in a sub-sample by industry classification to eliminate industrial effect, examining whether the effects of VC reputation on backed-firm 
Table 9 Robustness test 1: Regression results of $\mathrm{H} 1, \mathrm{H} 2$ and $\mathrm{H} 3$

\begin{tabular}{|c|c|c|c|c|c|c|c|}
\hline \multirow[t]{3}{*}{ Sample } & \multicolumn{7}{|l|}{$T f p_{t+1}$} \\
\hline & Model 1 & Model 2 & Model 3 & Model 4 & Model 5 & Model 6 & Model 7 \\
\hline & All sample & All sample & All sample & Low ID/ID =0 & Median ID & High ID & $\mathrm{ID}=1$ \\
\hline \multirow[t]{2}{*}{$\overline{V C l n v}$} & $-0.024^{* * *}$ & $0.115^{* *}$ & & $0.568^{* *}$ & 0.019 & $-0.039^{* * *}$ & $-2.568^{* * *}$ \\
\hline & $(0.007)$ & $(0.053)$ & & $(0.260)$ & $(0.014)$ & $(0.009)$ & $(0.080)$ \\
\hline \multirow[t]{2}{*}{$V C I n v \times I D$} & & $-0.180^{* * *}$ & & & & & \\
\hline & & $(0.067)$ & & & & & \\
\hline \multirow[t]{2}{*}{ ID } & & 0.415 & & & & & \\
\hline & & $(0.334)$ & & & & & \\
\hline \multirow[t]{2}{*}{ Intralnv } & & & $0.085^{*}$ & & & & \\
\hline & & & $(0.051)$ & & & & \\
\hline \multirow[t]{2}{*}{ Extralnv } & & & $-0.052^{* * *}$ & & & & \\
\hline & & & $(0.015)$ & & & & \\
\hline Controls & Included & Included & Included & Included & Included & Included & Included \\
\hline \multirow[t]{2}{*}{ Constant } & $71.752^{* * *}$ & $73.335^{* * *}$ & $71.780^{* * *}$ & $77.656^{* * *}$ & $73.433^{* * *}$ & $73.755^{* * *}$ & $76.894^{* * *}$ \\
\hline & $(1.855)$ & $(1.885)$ & $(1.853)$ & (3.104) & (3.796) & (2.549) & (11.18) \\
\hline$N$ & 1553 & 1328 & 1553 & 450 & 542 & 561 & 65 \\
\hline F & 39.04 & 30.81 & 37.49 & 8.83 & 17.56 & 19.99 & 3.94 \\
\hline$R^{2}$ & 0.338 & 0.342 & 0.340 & 0.291 & 0.390 & 0.412 & 0.606 \\
\hline
\end{tabular}

Notes. (1) Dependent variable is $T f p_{t+1}$. (2) The regression model is OLS. (3) $t$-statistics is reported in the parentheses. (4) ${ }^{*}$ denotes significance at the $10 \%$ level. ${ }^{*}$ denotes significance at the $5 \%$ level. ${ }^{* *}$ denotes significance at the $1 \%$ level

innovation are general to all industries or varied across different industries. Since the samples in the information technology industry, which is characterized as innovative, comprise $38.57 \%$, it is reasonable to divide our samples into an information technology subgroup (Tech group) and a non-information technology subgroup (Non-Tech group).

Table 14 reports the results. For different industries, the findings that VC intra-industrial reputation is good for entrepreneurial firm innovation while the extra-industrial reputation does harm remain robust (shown in Models 2 and 5). Also, Model 3 and

Table 10 Robustness test 1: Subgroup with VC types

\begin{tabular}{|c|c|c|c|c|}
\hline \multirow[t]{3}{*}{ Subgroup } & \multicolumn{4}{|l|}{$T f p_{t+1}$} \\
\hline & Model 1 & Model 2 & Model 3 & Model 4 \\
\hline & $\begin{array}{l}\text { Low Intralnv \& Low } \\
\text { Extralnv }\end{array}$ & $\begin{array}{l}\text { High Intralnv \& High } \\
\text { Extralnv }\end{array}$ & $\begin{array}{l}\text { High Intralnv \& Low } \\
\text { Extralnv }\end{array}$ & $\begin{array}{l}\text { Low Intralnv \& High } \\
\text { Extralnv }\end{array}$ \\
\hline \multirow[t]{2}{*}{$\overline{V C l n v}$} & -0.832 & $-0.017^{* *}$ & $0.564^{* *}$ & $-0.134^{* * *}$ \\
\hline & $(0.995)$ & $(0.008)$ & $(0.247)$ & $(0.049)$ \\
\hline Controls & Included & Included & Included & Included \\
\hline \multirow[t]{2}{*}{ Constant } & $60.875^{* * *}$ & $73.312^{* * *}$ & $76.479^{* * *}$ & $77.157^{* * *}$ \\
\hline & $(5.174)$ & $(2.766)$ & (2.938) & (3.433) \\
\hline$N$ & 278 & 517 & 492 & 266 \\
\hline$F$ & 7.23 & 16.78 & 10.11 & 10.86 \\
\hline$R^{2}$ & 0.360 & 0.378 & 0.300 & 0.456 \\
\hline
\end{tabular}

Notes. (1) Dependent variable is $T f p_{t+1}$. (2) The regression model is OLS. (3) $t$-statistics is reported in the parentheses. (4) ${ }^{* *}$ Denotes significance at the $5 \%$ level. ${ }^{* * *}$ Denotes significance at the $1 \%$ level 
Table 11 Robustness test 2: Regression results of $\mathrm{H} 2$ and subgroup with VC types

\begin{tabular}{|c|c|c|c|c|c|}
\hline \multirow[t]{3}{*}{ Subgroup } & \multicolumn{5}{|l|}{$T f p_{t+1}$} \\
\hline & Model 1 & Model 2 & Model 3 & Model 4 & Model 5 \\
\hline & $\begin{array}{l}\text { All } \\
\text { sample }\end{array}$ & $\begin{array}{l}\text { Low IntraRep_c \& } \\
\text { Low ExtraRep_c }\end{array}$ & $\begin{array}{l}\text { High IntraRep_c \& } \\
\text { High ExtraRep_c }\end{array}$ & $\begin{array}{l}\text { High IntraRep_c \& } \\
\text { Low ExtraRep_c }\end{array}$ & $\begin{array}{l}\text { Low IntraRep_c \& } \\
\text { High ExtraRep_c }\end{array}$ \\
\hline \multirow[t]{2}{*}{ IntraRep_c } & $0.312^{*}$ & & & & \\
\hline & $(0.178)$ & & & & \\
\hline \multirow[t]{2}{*}{ ExtraRep_c } & $-0.125^{* * *}$ & & & & \\
\hline & $(0.042)$ & & & & \\
\hline \multirow[t]{2}{*}{ VCRep } & & - & -0.097 & $1.077^{*}$ & $-0.151^{* *}$ \\
\hline & & & $(0.085)$ & $(0.653)$ & $(0.065)$ \\
\hline Controls & Included & Included & Included & Included & Included \\
\hline \multirow[t]{2}{*}{ Constant } & $71.020^{* * *}$ & $71.719^{* * *}$ & $82.827^{* * *}$ & $75.191^{* * *}$ & $74.936^{* * *}$ \\
\hline & (1.838) & $(2.936)$ & (6.279) & $(4.701)$ & (3.323) \\
\hline$N$ & 1553 & 939 & 119 & 195 & 300 \\
\hline$F$ & 39.07 & 25.77 & 5.69 & 3.65 & 15.79 \\
\hline$R^{2}$ & 0.349 & 0.348 & 0.472 & 0.295 & 0.348 \\
\hline
\end{tabular}

Notes. (1) Dependent variable is $T f p_{t+1}$. (2) The regression model is OLS. (3) $t$-statistics is reported in the parentheses. (4) ${ }^{*}$ denotes significance at the $10 \%$ level. ${ }^{* *}$ denotes significance at the $5 \%$ level. ${ }^{* *}$ denotes significance at the $1 \%$ level

Model 6 report a robust significant contingent effect of industrial distance. However, Model 1 shows that in the Tech subgroup, VC reputation does not have a significant effect on firm innovation, while the effect is still robust in the Non-Tech subgroup. Since in the Tech subgroup, the curse effect of extra-industrial reputation is offset by the blessing effect of VC intra-industrial reputation, the overall effect of VC reputation becomes insignificant. These results continue to indicate that the effect of $\mathrm{VC}$ reputation is contingent, determined by the effect of intra- and extra-industrial reputations.

\section{Conclusions}

\section{Theoretical implications}

Our research extends resource perspectives on VC reputation and generates novel insights for further research on entrepreneurship and innovation. Our contributions are as follows. First, our regression results evidence that in China's New OTC Market, $\mathrm{VC}$ reputation imposes a curse effect on entrepreneurial firm innovation, even over a long period of time, advancing literature by pointing to the "dark side" of VC reputation and how it can happen. We emphasize the dependent relationship where resourceconstrained entrepreneurial firms rely on reputable VC and act as low-power actors. In such a relationship, $\mathrm{VC}$ reputation may exert a negative impact by enabling resource outflows, or setting up barriers to resource cultivation, rather than being a promoter in resource inflows that prior work has focused on (Gu and Lu 2014; Krishnan et al. 2011; Lee et al. 2011).

Second, we show empirically that not all types of reputation are able to perform the same; their value to entrepreneurial firm innovation are contingent upon industrial distance. VC intra- and extra-industrial reputation and their different roles are firstly distinguished in our study, extending the literature of $\mathrm{VC}$ reputation. When it comes to 
Table 12 Robustness tests 1 and 2: Regression results of temporal effect

\begin{tabular}{llllll}
\hline & $T f p$ & $T f p_{t+1}$ & $T f p_{t+2}$ & $T f p_{t+3}$ & $T f p_{t+4}$ \\
\hline VCInv & $-0.017^{* * *}$ & $-0.024^{* * *}$ & $-0.035^{* * *}$ & $-0.050^{* * *}$ & $-0.056^{*}$ \\
& $(0.006)$ & $(0.007)$ & $(0.009)$ & $(0.013)$ & $(0.032)$ \\
Intralnv & $0.111^{* *}$ & $0.085^{*}$ & $0.146^{* *}$ & 0.143 & $0.449^{* *}$ \\
& $(0.045)$ & $(0.051)$ & $(0.067)$ & $(0.089)$ & $(0.188)$ \\
IntraRep_c & 0.024 & $0.312^{*}$ & $0.588^{* *}$ & $0.635^{*}$ & 0.650 \\
& $(0.125)$ & $(0.178)$ & $(0.289)$ & $(0.342)$ & $(0.469)$ \\
Extralnv & $-0.049^{* * *}$ & $-0.052^{* * *}$ & $-0.081^{* * *}$ & $-0.098^{* * *}$ & $-0.196^{* * *}$ \\
& $(0.013)$ & $(0.015)$ & $(0.019)$ & $(0.025)$ & $(0.060)$ \\
ExtraRep_c & $-0.030^{* *}$ & $-0.125^{* * *}$ & $-0.431^{* *}$ & $-0.545^{* *}$ & $1.487^{* *}$ \\
& $(0.014)$ & $(0.042)$ & $(0.185)$ & $(0.260)$ & $(0.724)$ \\
\hline
\end{tabular}

Notes. (1) Dependent variables are $T f p_{t}, T f p_{t+1}, T f p_{t+2}, T f p_{t+3}, T f p_{t+4}$, respectively. (2) The regression model is OLS. (3) $t-$ statistics is reported in the parentheses. (4) *denotes significance at the $10 \%$ level. **denotes significance at the $5 \%$ level. ${ }^{* * *}$ denotes significance at the $1 \%$ level

extra-industrial reputation, the benefits of resource inflows are not seemingly to offset the cost of resource outflows, and then the curse effect is manifested. However, it is the inflow not outflow that dominates the direction of resource transfer, thus providing empirical support for the blessing role of VC intra-industrial reputation. Put simply, the extraindustrial aspect of $\mathrm{VC}$ reputation deserves a lion's share of blame for the curse effect.

Our finding of the contingent value on industrial distance provides a feasible explanation for the mixed situation whereby VCs are both good and bad for their backed firm (Arvanitis and Stucki 2014; Bellavitis et al. 2014; Lee et al. 2011).

Table 13 Robustness test 3: Regression results using Tfp_ $W_{t+1}$ as the dependent variable

\begin{tabular}{|c|c|c|c|c|}
\hline & \multicolumn{4}{|l|}{$T f p \_w_{t+1}$} \\
\hline & Model 1 & Model 2 & Model 3 & Model 4 \\
\hline \multirow[t]{2}{*}{ VCRep } & & $-0.363^{* * *}$ & $1.147^{* * *}$ & \\
\hline & & $(0.120)$ & $(0.426)$ & \\
\hline \multirow[t]{2}{*}{$V C R e p \times I D$} & & & $-1.959^{* * *}$ & \\
\hline & & & $(0.591)$ & \\
\hline \multirow[t]{2}{*}{ ID } & & & -0.330 & \\
\hline & & & $(0.976)$ & \\
\hline \multirow[t]{2}{*}{ IntraRep } & & & & $0.439^{*}$ \\
\hline & & & & $(0.244)$ \\
\hline \multirow[t]{2}{*}{ ExtraRep } & & & & $-0.612^{* * *}$ \\
\hline & & & & $(0.163)$ \\
\hline Controls & Included & Included & Included & Included \\
\hline \multirow[t]{2}{*}{ Constant } & $86.698^{* * *}$ & $86.141^{* * *}$ & $90.381^{* * *}$ & $85.904^{* * *}$ \\
\hline & (4.515) & $(4.488)$ & $(4.925)$ & $(4.531)$ \\
\hline N & 1515 & 1515 & 1299 & 1515 \\
\hline$F$ & 107.24 & 102.58 & 73.96 & 94.34 \\
\hline$R^{2}$ & 0.303 & 0.308 & 0.322 & 0.311 \\
\hline
\end{tabular}

Notes. (1) Dependent variable is Tfp_w $w_{t+1}$. (2) The regression model is OLS. (3) $t$-statistics is reported in the parentheses. ${ }^{*}$ denotes significance at the $10 \%$ level. ${ }^{* * *}$ denotes significance at the $1 \%$ level 
Table 14 Robustness test 4: Regression results between Tech and Non-Tech subgroup

\begin{tabular}{|c|c|c|c|c|c|c|}
\hline \multirow[t]{3}{*}{ Subgroup } & \multicolumn{6}{|l|}{$T f p_{t+1}$} \\
\hline & Model 1 & Model 2 & Model 3 & Model 4 & Model 5 & Model 6 \\
\hline & Tech & Tech & Tech & Non-Tech & Non-Tech & Non-Tech \\
\hline \multirow[t]{2}{*}{ VCRep } & -0.030 & & $0.708^{* * *}$ & $-0.097^{* *}$ & & $0.455^{* *}$ \\
\hline & $(0.079)$ & & $(0.272)$ & $(0.041)$ & & $(0.141)$ \\
\hline \multirow[t]{2}{*}{$V C \operatorname{Rep} \times \mathbb{I D}$} & & & $-1.017^{* * *}$ & & & $-0.688^{* * *}$ \\
\hline & & & $(0.360)$ & & & $(0.170)$ \\
\hline \multirow[t]{2}{*}{ ID } & & & -0.164 & & & 0.249 \\
\hline & & & $(0.561)$ & & & (0.318) \\
\hline \multirow[t]{2}{*}{ IntraRep } & & $0.739^{* * *}$ & & & $0.147^{* *}$ & \\
\hline & & $(0.268)$ & & & $(0.064)$ & \\
\hline \multirow[t]{2}{*}{ ExtraRep } & & $-0.235^{* * *}$ & & & $-0.172^{* *}$ & \\
\hline & & $(0.082)$ & & & $(0.057)$ & \\
\hline Controls & Included & Included & Included & Included & Included & Included \\
\hline \multirow[t]{2}{*}{ Constant } & $96.596^{* * *}$ & $97.461^{* * *}$ & $98.410^{* * *}$ & $71.133^{* * *}$ & $70.934^{* * *}$ & $72.125^{* * *}$ \\
\hline & (5.614) & (5.860) & $(5.975)$ & $(2.501)$ & (2.494) & (3.077) \\
\hline N & 599 & 599 & 525 & 954 & 954 & 803 \\
\hline$F$ & 15.81 & 15.66 & 13.36 & 20.77 & 19.89 & 18.64 \\
\hline$R^{2}$ & 0.343 & 0.352 & 0.339 & 0.352 & 0.355 & 0.368 \\
\hline
\end{tabular}

Notes. (1) Dependent variable is $T f p_{t+1}$. (2) The regression model is OLS. (3) $t$-statistics is reported in the parentheses. (4) ${ }^{* *}$ denotes significance at the $5 \%$ level. ${ }^{* * *}$ denotes significance at the $1 \%$ level

\section{Practical implications}

Our findings may be of use for entrepreneurial firms when managing investment relationships with VC. Our conclusion that VC reputation is a curse rather than a blessing for entrepreneurial firms provides support for the suggestion by Pahnke et al. (2015) that "entrepreneurs might do well to view VCs as 'a necessary evil' and to avoid investors that back direct competitors" (p. 1355). However, this general suggestion may be overly simplistic for entrepreneurial firms. It is shown in our research that not all VC reputations are adverse, but rather, their true effects are the trade-off between resource inflows and outflows. The curse effect is manifested in the case of VC extra-industrial reputation, while it is weakened or even twists into a blessing in the case of VC intra-industrial reputation. Hence, for entrepreneurial firms, the best way to take advantage of resource inflows from $\mathrm{VC}$ but avoid the dark side of resource outflows is to access proper $\mathrm{VC}$, namely an intra-industrial expert with little extra-industrial investment.

Moreover, our research also contains practical implications for $\mathrm{VC}$ targeting the right firms to achieve a win-win situation. Within the VC industry, the investment portfolio, especially with distribution among various industries, is a widely adopted strategy to reduce investment risk, which is supported by our research sample data that the mean value of $\mathrm{VC}$ extra-industrial reputation is 0.658 , while intra-industrial reputation is 0.335 , almost half the former. However, our findings suggest that it is the extra-industrial element of $\mathrm{VC}$ reputations or investments that hinders backed firm innovation, generating the practical insight for $\mathrm{VC}$ that limiting investment deals to a few industries and positioning as an industry expert may be a wiser investment strategy. 


\section{Limitations and future research}

Our research has several implications for the current debate on the relationship between VC reputation and firm innovation. However, there are still several limitations which may imply potential avenues for future research. The first opportunity stems from our inability to observe what kinds of resource inflow or outflow, to what extent, and even how they flow. Future work may employ case study or other alternative methodologies to clarify the resource flow mechanism. The second drawback is the use of only one market, China's New OTC Market. A detailed analysis of one market is insufficient to generalize our findings. Future work can test this curse effect of VC reputation in other markets, and examine whether it is just a particular phenomenon in developing countries like China. If the answer is yes, it is of great significance to explain why.

Acknowledgements

Not applicable.

\section{Funding}

The research is supported by the National Social Science Fund of China (Project No. 17AJY012).

The research is supported by the Outstanding Innovative Talents Cultivation Funded Programs 2018 of Renmin University of China.

\section{Availability of data and materials}

Please contact author for data requests.

\section{Authors' contributions}

$\mathrm{LH}$ contributed to the overall writing; LG conceived the idea; YJ contributed to the data processing. All authors read and approved the final manuscript.

Ethics approval and consent to participate

Not applicable.

\section{Consent for publication}

Not applicable.

Competing interests

The authors declare that they have no competing interests.

\section{Publisher's Note}

Springer Nature remains neutral with regard to jurisdictional claims in published maps and institutional affiliations.

Received: 22 October 2018 Accepted: 26 February 2019

Published online: 23 May 2019

\section{References}

Arvanitis, S., \& Stucki, T. (2014). The impact of venture capital on the persistence of innovation activities of start-ups. Small Business Economics, 42(4), 849-870.

Auty, R. M. (1993). Sustaining development in mineral economies: The resource curse thesis. London: Routledge.

Baum, J. A. C., Calabrese, T., \& Silverman, B. S. (2000). Don't go it alone: Alliance network composition and startups' performance in Canadian biotechnology. Strategic Management Journal, 21(3), 267-294.

Bellavitis, C., Filatotchev, I., \& Kamuriwo, D. S. (2014). The effects of intra-industry and extra-industry networks on performance: A case of venture capital portfolio firms. Managerial \& Decision Economics, 35(2), 129-144.

Bernstein, S., Giroud, X., \& Townsend, R. R. (2016). The impact of venture capital monitoring. Journal of Finance, 71(4), $1591-1622$.

Brunnschweiler, C. N., \& Bulte, E. H. (2008). The resource curse revisited and revised: A tale of paradoxes and red herrings. Journal of Environmental Economics \& Management, 55(3), 248-264.

Chemmanur, T. J., Krishnan, K., \& Nandy, D. K. (2011). How does venture capital financing improve efficiency in private firms? A look beneath the surface. Review of Financial Studies, 24(12), 4037-4090.

Chemmanur, T. J., Loutskina, E., \& Tian, X. (2014). Corporate venture capital, value creation and innovation. Review of Financial Studies, 27(8), 2434-2473.

Chen, S., He, W. L., \& Zhang, R. (2017). Venturn capital and corporation innovation: Impact and potential mechaism. Management World, 1, 158-169.

Cohen, W. M., \& Levinthal, D. A. (1990). Absorptive capacity: A new perspective on learning and innovation. Administrative Science Quarterly, 35(1), 128-152.

Colombo, M. G., Franzoni, C., \& Rossi-Lamastra, C. (2015). Internal social capital and the attraction of early contributions in crowdfunding. Entrepreneurship Theory \& Practice, 39(1), 75-100. 
Croce, A., Martí, J., \& Murtinu, S. (2016). The impact of venture capital on the productivity growth of European entrepreneurial firms: "Screening" or "value added" effect? Journal of Business Venturing, 28(4), 489-510.

Deng, Z., \& Wang, Z. (2016). Early-mover advantages at cross-border business-to-business e-commerce portals. Journal of Business Research, 69(12), 6002-6011.

Dimov, D., \& Clercq, D. D. (2006). Venture capital investment strategy and portfolio failure rate: A longitudinal study. Entrepreneurship Theory \& Practice, 30(2), 207-223.

Dimov, D., \& Milanov, H. (2010). The interplay of need and opportunity in venture capital investment syndication. Journal of Business Venturing, 25(4), 331-348.

Dushnitsky, G., \& Lenox, M. J. (2005). When do incumbents learn from entrepreneurial ventures? Corporate venture capital and investing firm innovation rates. Research Policy, 34(5), 615-639.

Dushnitsky, G., \& Shaver, J. M. (2010). Limitations to interorganizational knowledge acquisition: The paradox of corporate venture capital. Strategic Management Journal, 30(10), 1045-1064.

Dutta, S., \& Folta, T. B. (2016). A comparison of the effect of angels and venture capitalists on innovation and value creation. Journal of Business Venturing, 37(1), 39-54.

Fombrun, C. J. (1996). Reputation: Realizing value from the corporate image. Boston: Harvard Business School Press.

Giannetti, M., Liao, G., \& Yu, X. (2015). The brain gain of corporate boards: Evidence from China. Journal of Finance, 70(4), 1629-1682.

Gompers, P., Kovner, A., \& Lerner, J. (2009). Specialization and success: Evidence from venture capital. Journal of Economics \& Management Strategy, 18(3), 817-844.

Gompers, P., Kovner, A., Lerner, J., \& Scharfstein, D. (2005). Venture capital investment cycles: The role of experience and specialization. Journal of Financial Economics, 81, 649-679.

Gompers, P., \& Lerner, J. (1999). Conflict of interest in the issuance of public securities: Evidence from venture capital. Journal of Law \& Economics, 42(1), 1-28.

Gu, Q., \& Lu, X. (2014). Unraveling the mechanisms of reputation and alliance formation: A study of venture capital syndication in China. Strategic Management Journal, 35(5), 739-750.

Gulati, R., \& Higgins, M. C. (2003). Which ties matter when? The contingent effects of interorganizational partnerships on IPO success. Strategic Management Journal, 24(2), 127-144.

Gylfason, T., \& Zoega, G. (2010). Natural resources and economic growth: The role of investment. The World Economy, 29(8), 1091-1115.

Hallen, B. L., \& Eisenhardt, K. M. (2012). Catalyzing strategies and efficient tie formation: How entrepreneurial firms obtain investment ties. Academy of Management Journal, 55(1), 35-70.

Hernandez, E., Sanders, W. G., \& Tuschke, A. (2015). Network defense: Pruning, grafting, and closing to prevent leakage of strategic knowledge to rivals. Academy of Management Journal, 58(4), 1233-1260.

Hochberg, Y. V., Ljungqvist, A., \& Lu, Y. (2007). Whom you know matters: Venture capital networks and investment performance. Journal of Finance, 62(1), 251-301.

Hsu, D. H. (2006). Venture capitalists and cooperative start-up commercialization strategy. Management Science, 52(2), 204-219.

Katila, R., Rosenberger, J. D., \& Eisenhardt, K. M. (2008). Swimming with sharks: Technology ventures, defense mechanisms and corporate relationships. Administrative Science Quarterly, 53(2), 295-332.

Khurana, R. (2002). Market triads: A theoretical and empirical analysis of market intermediation. Journal for the Theory of Social Behaviour, 32(2), 239-262.

Kleinbaum, A. M., \& Stuart, T. E. (2014). Inside the black box of the corporate staff: Social networks and the implementation of corporate strategy. Strategic Management Journal, 35(1), 24-47.

Kostopoulos, K., Papalexandris, A., Papachroni, M., \& Ioannou, G. (2011). Absorptive capacity, innovation, and financial performance. Journal of Business Research, 64(12), 1335-1343.

Krishnan, C. N. V., Ivanov, V. I., Masulis, R. W., \& Singh, A. K. (2011). Venture capital reputation, post-IPO performance and corporate governance. Journal of Financial \& Quantitative Analysis, 46(5), 1295-1333.

Lee, P. M., Pollock, T. G., \& Jin, K. (2011). The contingent value of venture capitalist reputation. Strategic Organization, 9(1), 33-69.

Levinsohn, J., \& Petrin, A. (2003). Estimating production functions using inputs to control for unobservables. Review of Economic Studies, 70(2), 317-341.

McDonald, J. F., \& Moffitt, R. A. (1980). The uses of tobit analysis. Review of Economics \& Statistics, 62(2), 318-321.

Megginson, W. L., \& Weiss, K. A. (1991). Venture capitalist certification in initial public offerings. Journal of Finance, 46(3), 879-903.

Nahata, R. (2008). Venture capital reputation and investment performance. Journal of Financial Economics, 90(2), 127-151.

Pahnke, E. C., McDonald, R., Wang, D., \& Hallen, B. (2015). Exposed: Venture capital, competitor ties, and entrepreneurial innovation. Academy of Management Journal, 58(5), 1334-1360.

Park, H. D., \& Steensma, H. K. (2012). When does corporate venture capital add value for new ventures? Strategic Management Journal, 33(1), 1-22

Pollock, T. G. (2004). The benefits and costs of underwriters' social capital in the U.S. IPO market. Strategic Organization, 2(4), 357-388.

Pollock, T. G., Porac, J. F., \& Wade, J. B. (2004). Constructing deal networks: Brokers as network "architects" in the U.S. IPO market and other examples. Academy of Management Review, 29(1), 50-72.

Rindova, V. P., Williamson, I. O., Petkova, A. P., \& Sever, J. M. (2005). Being good or being known: An empirical examination of the dimensions, antecedents, and consequences of organizational reputation. Academy of Management Journal, 48(6), 1033-1049.

Sahlman, W. A. (1990). The structure and governance of venture-capital organizations. Journal of Financial Economics, 27(2), 473-521.

Smith, S. W. (2014). Follow me to the innovation frontier? Leaders, laggards, and the differential effects of imports and exports on technological innovation. Journal of International Business Studies, 45(3), 248-274.

Sorenson, O., \& Stuart, T. E. (2001). Syndication networks and the spatial distribution of venture capital investments. American Journal of Sociology, 106(6), 1546-1588.

Stinchcombe, A. L. (1965). Organizations and social structure. In Handbook of Organizations.

Stuart, T. E., Hoang, H., \& Hybels, R. C. (1999). Interorganizational endorsements and the performance of entrepreneurial ventures. Administrative Science Quarterly, 44(2), 315-349.

Tang, Q., \& Li, W. (2018). Identifying M\&A targets and the information content of VC/PEs. China Journal of Accounting Research, 11(1), 33-50. 
Tian, X. (2012). The role of venture capital syndication in value creation for entrepreneurial firms. Review of Finance, 16(1), 245-283.

Veugelers, R. (1997). Internal R \& D expenditures and external technology sourcing. Research Policy, 26(3), 303-315.

Wang, Z. Y., Geng, T. C., \& Zhao, Y. H. (2018). An empirical study on venture capitalist reputation and NEEQ firm productivity. Journal of Beijing Technology and Business University (Social Sciences), 5, 116-126.

Zahra, S. A., \& George, G. (2002). Absorptive capacity: A review, reconceptualization, and extension. Academy of Management Review, 27(2), 185-203.

Zhang, L. (2015). Refining the art of reforming the corporate governance of chinese state-controlled listed companies: Venture capital and adaptive efficiency. Frontiers of Business Research in China, 9(2), 161-191.

Zhang, Y., \& Li, H. (2010). Innovation search of new ventures in a technology cluster: The role of ties with service intermediaries. Strategic Management Journal, 31(1), 88-109.

Zhu, X. M., \& Li, M. F. (2011). The dynamic impact of the entreprenuerial network on the resources acqusition: An evidence based on China's transitional economy. Management World, 6, 105-115.

Submit your manuscript to a SpringerOpen ${ }^{\circ}$ journal and benefit from:

- Convenient online submission

- Rigorous peer review

- Open access: articles freely available online

- High visibility within the field

- Retaining the copyright to your article

Submit your next manuscript at $\boldsymbol{\nabla}$ springeropen.com 